Jurnal Keperawatan Silampari

Volume 2, Nomor 2, Juni 2019

e-ISSN: 2581-1975

p-ISSN: 2597-7482

DOI: https://doi.org/10.31539/jks.v2i2.507

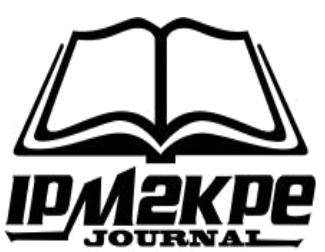

\title{
TERAPI MUROTTAL DENGAN AKUPRESUR TERHADAP TINGKAT KECEMASAN DAN KADAR GULA DARAH PADA PASIEN DENGAN PENYAKIT JANTUNG KORONER
}

\author{
Farid Hajiri ${ }^{1}$, Sri Endang Pujiastuti ${ }^{2}$, Joni Siswanto ${ }^{3}$ \\ Program Kebidanan Sains Terapan Pascasarjana, Poltekkes Kemenkes Semarang 1,2,3 \\ f_hajiri@yahoo.com ${ }^{1}$
}

\begin{abstract}
ABSTRAK
Tujuan penelitian ini untuk mengetahui pengaruh terapi kombinasi murottal dan akupresur terhadap tingkat kecemasan dan kadar gula darah pada pasien penyakit jantung koroner, serta mendiskripsikan tingkat kecemasan dan kadar gula darah pre dan post pada pemberian terapi kombinasi dan terapi non kombinasi, serta menganalisis pengaruh dan perbedaan terapi kombinasi dan non kombinasi terhadap tingkat kecemasan dan kadar gula darah. Penelitian ini merupakan penelitian analitik komparatif berpasangan dengan menggunakan desain experimental with control group pretest posttest design. Hasil signifikan pada uji repeated measurement Anova pada tingkat kecemasan didapatkan nilai $\mathrm{p}<0,05$ yang artinya ada pengaruh signifikan murottal dan akupresur terhadap tingkat kecemasan, pada kadar gula darah didapatkan nilai $\mathrm{p}>0,05$ yang artinya tidak ada pengaruh signifikan murottal dan akupresur terhadap kadar gula darah. Simpulan, terapi kombinasi antara murottal dengan akupresur selama 2x15 menit sehari lebih efektif dalam menurunkan kecemasan pasien jantung koroner pada pengukuran 1 dan pengukuran 2. Terapi murottal dengan akupresur dan terapi murottal tidak pengaruh terhadap gula darah pada pengukuran 1 dan pengukuran 2 .
\end{abstract}

Kata Kunci: Akupresur, Kadar Gula Darah, Kecemasan, Murottal Al-Quran, Penyakit Jantung Koroner

\section{ABSTRACT}

The purpose of this study was to determine the effect of murottal and acupressure combination therapy on anxiety levels and blood sugar levels in patients with coronary heart disease, as well as describing the level of anxiety and pre and post blood sugar levels in the administration of combination therapy and non-combination therapy, and analyze the effect and differences in therapy combination and non-combination of anxiety and blood sugar levels. This study was a paired comparative analytic study using an experimental design with a control group pretest posttest design. Significant results in the Anova repeated measurement test on anxiety levels obtained $p$ value $<0.05$ which means there is a significant influence of murottal and acupressure on anxiety levels, on blood sugar levels $p$ values $>0.05$ which means there is no significant effect of murottal and acupressure on blood sugar level. Conclusion, combination therapy between murottal with acupressure for $2 x 15$ minutes a day is more effective in reducing anxiety of coronary heart patients in measurement 1 and measurement 2. 
Murottal therapy with acupressure and murottal therapy has no effect on blood sugar in measurement 1 and measurement 2.

Keywords: Acupressure, Blood Sugar Levels, Anxiety, Al-Qur'an Murottal, Coronary Heart Disease

\section{PENDAHULUAN}

Penyakit jantung koroner (PJK) penyebab utama kematian dan kesakitan di banyak negara maju, bahkan juga di berbagai negara berkembang. Penyakit ini menyumbang sekitar 30\% dari total kematian di dunia. Penyakit jantung koroner adalah sebuah kondisi dimana dinding pembuluh darah arteri yang mensuplai darah ke otot jantung mengalami penebalan. Penebalan ini disebabkan oleh perkembangan lesi atau plak pada dinding arteri, yang disebut aterokslerosis. Keadaan ini membatasi pasokan darah ke otot jantung (miokardium) dan memberikan manifestasi seperti nyeri dada (angina) atau sesak nafas saat beraktivitas (Rufaidah MF, 2015).

Kecemasan yang dialami oleh penderita penyakit jantung dapat menyebabkan spasme pembuluh darah sehingga dapat menyebabkan infark miokard yang disebut dengan serangan jantung dan akan mempengaruhi penyembuhan. Mekanisme yang menyebabkan kecemasan meningkatkan risiko penyakit jantung koroner yang fatal termasuk hiperventilasi yang terjadi selama serangan akut yang dapat menyebabkan spasme koroner dan dapat menyebabkan kegagalan ventrikel sehingga dapat menyebabkan aritmia (Malan, Muller, 2013). Kecemasan merupakan salah satu bentuk emosi yang menyebabkan ketegangan jiwa dan bila hal ini tidak tersalurkan dengan baik, emosi yang tertekan akan mencetuskan akibat-akibat yang negatif, yang berhubungan dengan berbagai sistem organ tubuh. Bila yang terkena adalah jantung, dampaknya akan meluas. Oleh karena itu kecemasan dan ketegangan berpengaruh terhadap sistem kardiovaskuler yang dapat tercermin pada detak jantung yang berdebar-debar dan sesak nafas (Soeharto I, 2004).

Metode yang dapat digunakan untuk mengontrol kecemasan adalah dengan terapi farmakologis dan non-farmakologis. Terapi farmakologi yang pada pasien yang nyeri dan gelisahmenggunakan obat Benzodiazepin, memiliki efek samping seperti; penurunan hemodinamik, defisit memori, resistensi obat, ketergantungan dan kecanduan.terapi akupresur adalah salah satu terapinon-farmakologis yang bisa diberikan untuk mengatasi kecemasanpasien dengan terapi komplementer (Widyatuti W, 2008).

Akupresur merupakan tindakan yang mudah dilakukan dan memiliki banyak keuntungan. Akupresur sangat praktis karena dengan sentuhan memiliki keajaiban tersendiri yang sangat berguna untuk menghilangkan rasa lelah pada tubuh, memperbaiki sirkulasi darah, merangsang tubuh untuk mengeluarkan racun. Penekanan ujung-ujung jari tangan pada daerah tertentu dipermukaan kulit yang berdampak positif terhadap kondisi fisik, mental dan sosial (Majid, 2014).

Rangsangan manual pada titik akupresur terbukti dapat meningkatkan produksi serotonin dan endorphin yang berperan dalam meningkatkan regulasi kortisol serum. Endorphin merupakan opiat alami yang diproduksi di dalam tubuh, dapat memicu respon menenangkan dan membangkitkan semangat di dalam tubuh, memiliki efek positif pada emosi, mengurangi kecemasan, menyebabkan relaksasi dan normalisasi fungsi tubuh (Hmwe NTT, 2015). Sedangkan serotonin mempunyai fungsi mengatur mood dan tidur (Yudi, 2014). 
Jenis terapi komplementer yang lain yang saat ini dikembangkan dengan tujuan untuk merelaksasikan pasien dan sedang mulai digunakan adalah jenis terapi religi. Terapi murottal bekerja pada otak, dimana ketika didorong dengan rangsangan dari luar (terapi Al-Quran) maka otak memproduksi zat kimia yang disebut neuropeptide. Molekul-molekul ini mengangkut reseptor-reseptor mereka yang ada didalam tubuh sehingga tubuh memberi umpan balik berupa rasa nyaman. Bacaan Al-Quran secara murottal mempunyai efek relaksasi dan dapat menurunkan kecemasan dan meningkatkan kualitas tidur apabila didengarkan dalam tempo murottal berada antara 60-70 dh secara konstan, tidak ada perubahan irama yang mendadak, dan dalam nada yang lembut (Lestari D, 2015; Endiyono, 2016).

Dengan terapi murottal, kualitas kesadaran seseorang terhadap Tuhan akan meningkat, baik orang tersebut tahu arti Al-Quran maupun tidak. Dalam hal ini kesadaran akan meningkatkan kepasrahan seseorang akan kuasa Allah SWT, dalam keadaan ini otak berada pada gelombang alpha, merupakan gelombang otak pada frekuensi 7-14 Hz, merupakan keadaan energi otak yang optimal yang dapat menurunkan hingga menghilangkan stress. Dalam keadaan otak yang tenang seseorang dapat berpikir dengan jernih dan dapat membentuk koping atau harapan yang positif akan dirinya.

Akupresur dan Murottal belum pernah dilakukan oleh perawat di ruang perawatan rumah sakit sebagai salah satu modalitas terapi keperawatan untuk menurunkan tingkat kecemasan. Akupresur dan murottal adalah salah suatu intervensi keperawatan yang dapat dilakukan oleh perawat secara independen dan merupakan salah satu intervensi yang tercantum dalam Nursing Intervention classifications.

\section{METODE PENELITIAN}

Penelitian ini merupakan penelitian analitik komparatif berpasangan dengan menggunakan desain experimental with control group pretest posttest design. Pada desain ini, terdapat dua kelompok yaitu kelompok intervensi dan kelompok kontrol. Kelompok intervensi diberikan perlakuan berupa murottal dan akupresur sedangkan kelompok kontrol diberikan murottal saja dengan durasi masing-masing 15 menit selama 2 hari. Penelitian ini dilakukan untuk mengetahui apakah ada pengaruh hubungan sebab akibat setelah dilakukan perlakuan pada kelompok intervensi. Kemudian setelah perlakuan diberikan, dilakukan penilaian tingkat kecemasan dan gula darah kemudian dibandingkan apakah ada perbedaan pada kelompok intervensi dan kelompok kontrol.

Sebanyak 30 responden dipilih dengan metode stratified random sampling dengan kriteria: 1) Pasien yang sadar, tidak ada gangguan komunikasi; 2) Pasien yang beragama islam dan sehat rohani; 3) Pasien yang masuk dalam kriteria pasien kritis; 4) Pasien yang mengalami kecemasan dengan skala $>40$.

\section{Instrumen}

Zung Self-Rating Anxiety Scale digunakan sebagai instrumen kecemasan untuk mengukur kecemasan pada pasien penyakit jantung koroner sebelum dan sesudah intervensi. Skala terdiri dari 20 item pernyataan, dengan kategori selalu; kadangkadang; jarang; dan tidak pernah. Mengadopsi Zung Self-Rating Anxiety Scale dari penelitian Lestari (2015) yang sudah diuji validitas dan reabilitas pada 16 pasien cemas dengan diangnosa penyakit jantung koroner (PJK) yang menunjukkan validitas memiliki korelasi yang tinggi dan reabilitas yang sempurna dimana semua item 
pernyataan ZS-RAS memiliki R hitung lebih besar dari 0.63 dan nilail Cronbach's Alpha lebih dari 0.63 .

\section{Analisa Data}

Uji normalitas data menggunakan shapiro-wilk karena sampel kurang dari 50, hasil uji normalitas menunjukkan hasil $>0.05$ maka selanjutnya digunakan uji statistik repeated measurement anova dengan menggunakan SPSS versi 20.

\section{HASIL PENELITIAN}

Tabel. 1

Karakteristik Responden Berdasarkan Usia, Jenis Kelamin, dan Obat Sedatif pada Kelompok Intervensi dan Kontrol

\begin{tabular}{|c|c|c|c|c|c|}
\hline \multirow[t]{3}{*}{ Variabel } & \multicolumn{4}{|c|}{ Kelompok Responden } & \multirow{3}{*}{$\begin{array}{c}\mathrm{P} \\
\text { Value }\end{array}$} \\
\hline & \multicolumn{2}{|c|}{ Intervensi } & \multicolumn{2}{|c|}{ Kontrol } & \\
\hline & $\mathrm{N}$ & $\%$ & $\mathrm{~N}$ & $\%$ & \\
\hline Usia (Mean \pm SD) & \multicolumn{2}{|c|}{$15(52.87 \pm 4.580)$} & \multicolumn{2}{|c|}{$15(52.07 \pm 4.803)$} & \\
\hline $26-45$ & 1 & 6,7 & 1 & 6,7 & \\
\hline $46-65$ & 14 & 93,3 & 14 & 93,3 & 0.707 \\
\hline Total & 15 & 100 & 15 & 100 & \\
\hline \multicolumn{6}{|l|}{ Jenis Kelamin } \\
\hline Laki-laki & 8 & 53,3 & 8 & 53,3 & \\
\hline Perempuan & 7 & 46,7 & 7 & 46,7 & 1.000 \\
\hline Total & 15 & 100 & 15 & 100 & \\
\hline \multicolumn{6}{|l|}{ Obat Sedatif } \\
\hline Alprazolam & 8 & 53,3 & 8 & 53,3 & \\
\hline Lorazepam & 7 & 46,7 & 7 & 46,7 & 1.000 \\
\hline Total & 15 & 100 & 15 & 100 & \\
\hline \multicolumn{6}{|l|}{ Rumah Sakit : } \\
\hline RSUD Ambarawa & 8 & 53,3 & 8 & 53,3 & \\
\hline RSUD Ungaran & 7 & 46,7 & 7 & 46,7 & \\
\hline Total & 15 & 100 & 15 & 100 & \\
\hline
\end{tabular}

* Levene test

Tabel 1 menunjukkan bahwa usia antara kelompok intervensi dan kontrol tidak berbeda ( $\mathrm{p}=0.707)$. Rata-rata usia kelompok intervensi dan kontrol berada pada rentang usia 46-65 (Lansia). Distribusi responden menurut jenis kelamin kedua kelompok tidak berbeda $(\mathrm{p}=1.000)$. Jumlah responden laki-laki dan perempuan sama banyak yaitu 15 orang laki-laki dan 15 orang perempuan (100\%). Distribusi responden menurut jenis obat sedatif kedua kelompok yang menggunakan obat jenis alprazolam 16 orang $(53.5 \%)$ dan yang menggunakan obat jenis lorazepam 14 orang (46.6\%).

Tabel. 2

Distribusi Tingkat Kecemasan pada Kelompok Intervensi dan Kontrol

\begin{tabular}{|c|c|c|c|c|c|c|c|c|c|c|c|c|}
\hline \multirow{3}{*}{ Kecemasan } & \multicolumn{6}{|c|}{ Perlakuan } & \multicolumn{6}{|c|}{ Control } \\
\hline & \multicolumn{2}{|c|}{ Pre-test } & \multicolumn{2}{|c|}{ Post-tes 1} & \multicolumn{2}{|c|}{ Post-tes 2} & \multicolumn{2}{|c|}{ Pre-test } & \multicolumn{2}{|c|}{ Post-tes 1} & \multicolumn{2}{|c|}{ Post-tes 2} \\
\hline & $\mathrm{n}$ & $\%$ & $\mathrm{n}$ & $\%$ & & & $\mathrm{n}$ & $\%$ & $\mathrm{n}$ & $\%$ & $\mathrm{n}$ & $\%$ \\
\hline Tidak Cemas & 0 & 0.00 & 0 & 0.00 & 0 & 0.00 & 0 & 0.00 & 0 & 0.00 & 2 & 13.3 \\
\hline Cemas Ringan & 2 & 13.3 & 9 & 60.0 & 7 & 46.7 & 5 & 33.3 & 6 & 40.0 & 9 & 60.0 \\
\hline Cemas Sedang & 8 & 53.3 & 6 & 40.0 & 7 & 46.7 & 8 & 53.3 & 7 & 46.7 & 3 & 20.0 \\
\hline Cemas Berat & 5 & 33.3 & 0 & 0.00 & 1 & 6.70 & 2 & 13.3 & 2 & 13.3 & 1 & 6.70 \\
\hline
\end{tabular}




\begin{tabular}{|c|c|c|c|c|c|c|}
\hline \multirow{3}{*}{ Kecemasan } & \multicolumn{3}{|c|}{ Perlakuan } & \multicolumn{3}{|c|}{ Control } \\
\hline & Pre-test & Post-tes 1 & $\begin{array}{c}\text { Post-tes } \\
2\end{array}$ & Pre-test & Post-tes 1 & $\begin{array}{l}\text { Post- } \\
\text { tes } 2\end{array}$ \\
\hline & $\%$ & $\%$ & & $\%$ & $\%$ & $\mathrm{n} \quad \%$ \\
\hline$($ Mean \pm SD $)$ & $3.20+0.676$ & $2.40+0.507$ & $\begin{array}{l}2.60+ \\
0.632\end{array}$ & $2.80 \pm 0.676$ & $2.73+0.704$ & $\begin{array}{c}2.20 \pm 0 \\
.775\end{array}$ \\
\hline
\end{tabular}

Tabel 2 menunjukkan bahwa intervensi murottal dengan akupresur dapat menurunkan tingkat kecemasan dari post 1 sampai dengan post 2. Pada kedua kelompok mengalami penurunan kecemasan, namun kelompok Intervensi lebih rendah dalam tingkat kecemasan daripada kelompok kontrol pada post $1(2.40+0.507)$.

Tabel. 3

Distribusi Gula Darah pada Kelompok Intervensi dan Kontrol

\begin{tabular}{lll}
\hline \multicolumn{1}{c}{ Hari } & \multicolumn{1}{c}{ Variabel } & \multirow{2}{*}{ Kean \pm SD } \\
\hline Pre & Intervensi & $177.20 \pm 19.332$ \\
\cline { 2 - 3 } & Kontrol & $174.93 \pm 18.885$ \\
\hline Pengukuran 1 & Intervensi & $173.33 \pm 18.007$ \\
\cline { 2 - 3 } & Kontrol & $170.93 \pm 19.367$ \\
\hline Pengukuran 2 & Intervensi & $173.27 \pm 17.886$ \\
\cline { 2 - 3 } & Kontrol & $171.47 \pm 18.631$ \\
\hline
\end{tabular}

Tabel 3 menunjukkan bahwa intervensi Murottal dan Akupresur dapat menurunkan gula darah.

Tabel. 4

Analisis Hasil Uji Repeated Measure Anova (Tests of Within-Subjects Effects) terhadap Kecemasan antara Kelompok Intervensi dan Kelompok Kontrol

\begin{tabular}{cccccc}
\hline Source & $\begin{array}{c}\text { Type III Sum of } \\
\text { Squares }\end{array}$ & $d f$ & Mean Square & $F$ & Sig. \\
\hline Kecemasan & 1788.8 & 2 & 894.4 & 29.206 & .000 \\
\hline
\end{tabular}

Tabel 4 menunjukkan bahwa nilai F untuk faktor "kecemasan" secara statistik berbeda nyata $\mathrm{F}(1788.8,2) \mathrm{p}=0.00)$. Maka dapat disimpulkan terdapat perbedaan yang signifikan secara keseluruhan terhadap kecemasan setelah diberikan murotal dan akupressur pada pengukuran 1 dan pengukuran 2 .

Tabel. 5

Analisis Perbedaan Kecemasan Sebelum dan Sesudah Perlakuan antara Kelompok Intervensi dan Kelompok Kontrol (Pairwise Comparisons)

\begin{tabular}{lccc}
\hline Kelompok responden & (Pre) Sesi & (Post) Sesi & $p$ \\
\hline Intervensi & 1 & 3 & .005 \\
\cline { 2 - 4 } & 1 & 2 & .000 \\
\cline { 2 - 4 } & 2 & 3 & .016 \\
\hline Kontrol & 1 & 3 & .000 \\
\cline { 2 - 4 } & 2 & 3 & .378 \\
\hline
\end{tabular}


Tabel 5 menunjukkan perbedaan kecemasan sebelum dan sesudah perlakuan. Intervensi murotal dan akupresur berpengaruh signifikan dalam menurunkan kecemasan pada pre dengan pengukuran 1 , pre dengan pengukuran 2 , dan pengukuran 2 dengan pengukuran 3. Pada kelompok kontrol terlihat bahwa ada pengaruh yang signifikan pada pre dengan pengukuran 3 dan pada pengukuran 2 dan pengukuran 3 sedangkan pada pre dan pengukuran 2 belum menunjukkan pengaruh yang signifikan.

Tabel. 6

Analisis Perbedaan Kecemasan antara Kelompok Intervensi dan Kelompok Kontrol

\begin{tabular}{clrrrr}
\hline Variabel & & \multirow{2}{*}{ Mean } & \multicolumn{2}{c}{ SD } & \multirow{2}{*}{$p$} \\
\hline Kecemasan & Kelompok & & & \\
\hline Pre & Intervensi & 62 & 7.241 & \multirow{2}{*}{337} \\
\cline { 2 - 4 } & Kontrol & 59 & 9.426 & \\
\hline Pengukuran 1 & Intervensi & 49.93 & 9.625 & \multirow{2}{*}{041} \\
\cline { 2 - 4 } & Kontrol & 57.47 & 9.680 & \\
\hline Pengukuran 2 & Intervensi & 55.67 & 8.641 & \multirow{2}{*}{002} \\
\cline { 2 - 4 } & Kontrol & 43.73 & 10.159 & \\
\hline
\end{tabular}

Tabel 6 menunjukkan bahwa ada perbedaan yang bermakna antara kecemasan kelompok intervensi dengan kelompok kontrol pada pengukuran 1 dan pengukuran 2 . Perbedaan lebih signifikan terjadi pada pengukuran 2.

Tabel. 7

Analisis Hasil Uji Repeated Measure Anova (Tests of Within-Subjects Effects) Gula Darah antara Kelompok Intervensi dan Kelompok Kontrol

\begin{tabular}{cccccc}
\hline Source & Type III Sum of Squares & Df & Mean Square & \multirow{2}{*}{$F$} & Sig. \\
\hline Gula darah & 292.156 & 2 & 146.078 & 6.097 & .004 \\
\hline
\end{tabular}

Tabel 7 menunjukkan bahwa nilai F untuk faktor "gula darah" secara statistik berbeda nyata $\mathrm{F}(292.156,2) \mathrm{p}=0.004$. Maka dapat disimpulkan terdapat perbedaan yang signifikan secara keseluruhan terhadap gula darah setelah diberikan murrotal dan akupresur pengukuran 1 dan pengukuran 2 .

Tabel. 8

Analisis perbedaan Gula Darah Sebelum dan Sesudah Perlakuan antara Kelompok Intervensi dan Kelompok Kontrol (Pairwise Comparisons)

\begin{tabular}{lccl}
\hline Kelompok responden & (Pre) Sesi & (Post) Sesi & $p$ \\
\hline Intervensi & & & \\
\cline { 2 - 4 } & 1 & 3 & .075 \\
\cline { 2 - 4 } & 2 & 2 & .080 \\
\hline Kontrol & 1 & 3 & .928 \\
\cline { 2 - 4 } & 1 & 2 & .114 \\
\cline { 2 - 4 } & 2 & 3 & .071 \\
\hline
\end{tabular}

Tabel 8 menunjukkan perbedaan gula darah sebelum dan sesudah perlakuan. Intervensi murotal dan akupresur tidak berpengaruh signifikan dalam menurunkan gula darah responden baik pada kelompok Intervensi maupun kelompok kontrol. 
Tabel. 9

Analisis Perbedaan Gula Darah antara Kelompok Intervensi dan Kelompok Kontrol

\begin{tabular}{clllll}
\hline \multicolumn{2}{c}{ Variabel } & & Mean & SD & $p$ \\
\hline Gula Darah & Kelompok & & & \multirow{2}{*}{ SD } \\
\hline Pre & Intervensi & 177.20 & 19.332 & \multirow{2}{*}{748} \\
\cline { 2 - 4 } & Kontrol & 174.93 & 18.885 & \\
\hline Pengukuran 1 & Intervensi & 173.33 & 18.007 & \multirow{2}{*}{728} \\
\cline { 2 - 4 } & Kontrol & 170.93 & 19.367 & \\
\hline Pengukuran 2 & Intervensi & 173.27 & 17.886 & \multirow{2}{*}{789} \\
\cline { 2 - 4 } & Kontrol & 171.47 & 18.631 & \\
\hline
\end{tabular}

Tabel 9 menunjukkan bahwa tidak ada perbedaan yang bermakna antara gula darah kelompok intervensi dengan kelompok kontrol pada pre, pengukuran 1, pengukuran $2(\mathrm{p}=0.748, \mathrm{p}=0.728, \mathrm{p}=0.789)$. Kedua kelompok sama-sama mengalami penurunan gula darah. Walaupun demikian baik kelompok intervensi maupun kelompok kontrol tidak menunjukkan pengaruh yang signifikan di setiap pengukuran.

\section{PEMBAHASAN}

Berdasarkan uji statistik menggunakan levene test of homogenety of variances menunjukkan bahwa tidak terdapat perbedaan antara kelompok perlakuan dengan kelompok kontrol pada karakteristik subyek penelitian berdasarkan usia $\mathrm{p}=0.707$, jenis kelamin $\mathrm{p}=1.000$. Hasil tersebut menunjukkan bahwa karakteristik usia dan jenis kelamin mempunyai varian yang setara/homogen.

Rata-rata usia kelompok intervensi dan kontrol berada pada rentang usia 46-65 (Lansia). Hal ini sesuai dengan penelitian oleh Wiyatno (2017) bahwa sebagian besar responden yang mengalami PJK berada pada rentang usia 41-59 tahun (Wiyatno, 2017). Sejalan dengan yang diungkapkan Kasron (2012) bahwa ada hubungan antara umur dan kematian akibat penyakit jantung koroner. Sebagian besar kasus terjadi pada laki-laki berusia 35-44 tahun dan resiko akan lebih meningkat seiring dengan bertambahnya usia (Kasron, 2012).

Kadar kolesterol pada laki-laki dan perempuan meningkat pada usia 20 tahun. Pada laki-laki kolesterol meningkat hingga usia 50 tahun. Pada perempuan yang belum menopause (usia 45-50) kadar kolesterol lebih rendah daripada laki-laki. Pada perempuan yang sudah menopause kadar esterogen dalam tubuhnya menurun sehingga resiko terkena penyakit jantung koroner sebanding dengan laki-laki. Teori mengatakan bahwa hormon esterogen dapat melebarkan pembuluh darah, sehingga menurunkan risiko terkena penyakit jantung koroner dan stroke. Hal inilah yang kemudian menyebabkan perempuan yang sudah menopause memiliki resiko lebih tinggi terkena PJK daripada perempuan yang belum menopause, dalam arti bahwa semakin tua usia seorang perempuan maka resiko terkena PJK juga akan semakin tinggi (Islamee AU, 2008).

Distribusi responden menurut jenis kelamin kedua kelompok sama banyak yaitu 15 orang laki-laki dan 15 orang perempuan. Berbeda dengan penelitian oleh Nugraha (2017) bahwa sebagian besar kecemasan di alami oleh pasien perempuan (Nugraha DA, 2017). Laki-laki mempunyai risiko lebih tinggi untuk menderita penyakit karsdiovaskular lebih awal, laki-laki juga mempunyai risiko lebih besar terhadap morbiditas dan mortalitas kardiovaskular (Islamee, 2008).

Sundstrom et al, (2004) mengemukakan bahwa sekitar 18-240 laki-laki antara usia 40-64 tahun memiliki hubungan antara miokard iskemik, faktor resiko dan kemtian 
akibat PJK. Faktor resiko PJK yang utama adalah : Hipertensi, Hiperkolesterolemia, dan merokok. Merokok memiliki efek menyebabkan beban miokard bertambah karena rangsangan oleh katekolamin dan menurunnya konsumsi $\mathrm{O} 2$ akibat inhalasi $\mathrm{CO}$ sehingga dapat menyebabkan takikardi, vasokonstriksi pembuluh darah, merubah permeabilitas dinding pembuluh darah dan merubah $5-10 \% \mathrm{Hb}$ menjadi carboksi-Hb (Sundstrom J, 2004).

Hasil penelitian menunjukkan kecemasan kelompok perlakuan pre-test mengalami kecemasan berat sebanyak $53.3 \%$ dengan nilai rerata 3.2 $\pm 0,676$ terjadi penurunan kecemasan setelah dilakukan murottal dengan akupresur pada pengukuran post-test 1 didapatkan sebagian besar responden mengalami kecemasan berat sebanyak $40.0 \%$ dengan nilai rerata $2.4 \pm 0,507$.

Kecemasan pada kelompok kontrol pada pre-test didapatkan sebanyak $53.3 \%$

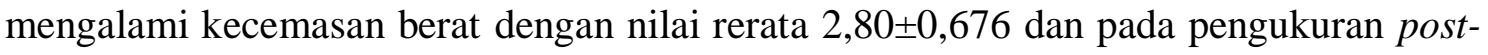
test 1 didapatkan sebagian besar responden sebanyak $46.7 \%$ mengalami kecemasan sedang dengan rerata 2,73 $\pm 0,704$, terlihat baik kelompok perlakuan dan kelompok kontrol mengalami penurunan skala cemas. Tetapi penurunan pada kelompok perlakuan lebih besar dan signifikan dibanding dengan kelompok kontrol.

Penelitian yang dilakukan oleh An $\mathrm{K}$ et al menunjukkan bahwa puncak kecemasan pada pasien dengan AMI akan hadir selama 12 jam setelah masuk, kemudian menurun secara bertahap dari 24 jam setelah masuk. Tingkat kecemasan kemudian tetap stabil 24-60 jam setelah masuk, dan meningkat ketika dipindahkan dari ICCU ke bangsal umum (An K et al, 2004). Sejalan dengan penelitian Mardiyono (2012) bahwa terlihat rata rata cemas yang dialami pasien acute myocardial infarction pada level sedang (Mardiyono, 2012).

Dengan begitu pada pasien AMI yang tidak mendapatkan terapi terkait dengan kecemasannya maka kecemasan akan menetap secara sementara pada kecemasan sedang dan tidak mengalami penurunan pada rentang 24 hingga 60 jam setelah masuk ke ruang ICCU.

Hasil penelitian menunjukkan bahwa terjadi penurunan gula darah pada kelompok intervensi dan kelompok kontrol pada setiap pengukuran. Fluktuasi nilai kadar gula darah sewaktu dipengaruhi oleh banyak faktor, antara lain adalah kemampuan responden dalam beraktifitas, kemampuan responden dalam asupan nutrisi sediaan rumah sakit dan kepatuhan terhadap ketersediaan diit dari rumah sakit. Gangguan kardiovaskuler menyebabkan responden mengalami sesak nafas karena terjadi penurunan cardiacout put. Kondisi demikian kurang memungkinkan bagi responden untuk beraktifitas yang cukup guna memasukkan glukosa darah ke dalam sel, hal ini berakibat kecenderungan terjadinya peningkatan nilai kadar gula darah sewaktu pada pasien dengan gangguan kardiovaskuler (Nugraha, 2017).

Kadar glukosa darah dipengaruhi oleh faktor endogen dan eksogen. Faktorendogen yaitu humoral factor seperti hormon insulin, glukagon, kortisol; sistemreseptor di otot dan sel hati. Faktor eksogen antara lain jenis dan jumlah makananyang dikonsumsi serta aktivitas fisik yang dilakukan (Setiawan, 2012).

Permasalahan yang muncul pada pasien terkait dengan diit adalah ketidak patuhan terhadap konsumsi diit yang disediakan oleh Rumah Sakit. Responden merasa diit dari Rumah Sakit kurang berasa, kurang gurih dan sebagainya, benar seperti itu karena diit untuk pasien dengan gangguan kardiovaskuler salah satunya adalah rendah garam. Responden meminta keluarga responden untuk membelikan makan dari luar RS tanpa izin perawat atau tenaga kesehatan lain yang menanganinya. Faktor seperti itu menjadi 
faktor confounding, penelitian gula darah sewaktu menjadi berkurang kekuatannya (Nugraha, 2017).

Riset menunjukkan bahwa gula darah yang tinggi terkait dengan resiko terjadinya Coronary Artery Disease (CAD). Nielson et al, (2006) dalam penelitiannya mengemukakan bahwa glukosa pagi dasar yang lebih tinggi (100-126 vs $100 \mathrm{mg} / \mathrm{dl}$ ) terkait dengan tingkat kejadian infark miokard 53,9\% lebih besar, akut 18,6\% lebih tinggi tingkat kejadian sindrom koroner, dan 26,4\% lebih banyak untuk resep nitratbaru (semua $p<0,05$ ) (Nielson C et al, 2006).

Hasil penelitian menunjukkan bahwa nilai F untuk faktor "kecemasan" secara statistik berbeda nyata $F(1788.8,2) \mathrm{p}=0.00$. Maka dapat disimpulkan terdapat perbedaan yang signifikan secara keseluruhan terhadap kecemasan setelah diberikan murotal dan akupressur pada pengukuran 1 dan pengukuran 2 .

Hasil dari penelitian ini sesuai dengan hasil penelitian medis terbaru yang dituliskan oleh Alkaheel (2011) memastikan akan pentingnya optimisme dan berita gembira, dan memperingatkan bahaya pesimisme, terutama terhadap pasien jantung. Sebuah penelitian di Amerika menyatakan bahwa seseorang yang berjiwa pesimis dapat membinasakan dirinya, terutama bagi seorang yang mengidap penyakit jantung. Dalam penelitian menunjukkan adanya tingkat kerentanan bagi penyakit jantung yang berakibat pada kematian, terutama pada saat terjadi sikap pesimis yang memberikan pengaruh pada kondisi kesehatan jantungnya (Al-Kaheel, 2011). Terapi murottal memiliki aspek yang sangat diperlukan dalam mengatasi kecemasan, murottal memiliki kemampuan untuk membentuk suatu koping baru untuk mengatasi kecemasan. Sehingga secara garis besar terapi murottal memiliki dua poin penting, yakni memiliki irama yang indah dan juga secara psikologis dapat memotivasi dan memberikan dorongan semangat seseorang untuk menghadapi problem yang sedang dihadapinya (Faradisi, 2012).

Terapi murottal memberikan dampak psikologis kearah positif, hal ini dikarenakan ketika murottal diperdengarkan dan sampai ke otak, maka murottal ini akan diterjemahkan oleh otak. Dengan terapi murottal, kualitas kesadaran seseorang terhadap Tuhan akan meningkat, baik orang tersebut tahu arti Al-Quran maupun tidak. Dalam hal ini kesadaran akan meningkatkan kepasrahan seseorang akan kuasa Allah SWT, dalam keadaan ini otak berada pada gelombang alpha, merupakan gelombang otak pada frekuensi 7-14 Hz, merupakan keadaan energi otak yang optimal yang dapat menurunkan hingga menghilangkan stress. Dalam keadaan otak yang tenang seseorang dapat berpikir dengan jernih dan dapat membentuk koping atau harapan yang positif akan dirinya (Faradisi, 2012).

Terapi religi dapat mempercepat penyembuhan, hal ini telah dibuktikan oleh berbagai ahli seperti yang dilakukan Ahmad al Kahdi, direktur utama islamic medicine institutefor education and research di Florida, Amerika Serikat. Hasil penelitian tersebut menunjukkan hasil positif bahwa mendengarkan ayat suci Al-Quran memiliki pengaruh yang signifikan dalam menurunkan ketegangan urat saraf reflektif dan hasil ini tercatat dan terukur secara kuantitatif dan kualitatif oleh sebuah alat berbasis komputer (Faradisi, 2012).

Hasil analisis statistik menunjukkan tingkat kecemasan pada kelompok perlakuan yang diberikan murottal dengan akupresur dengan durasi \pm 15 menit yang diberikan 2 kali sehari terdapat penurunan. Terdapat penurunan yang bermakna pada rerata nilai kecemasan sebelum dan sesudah diberikan murottal dengan akupresur pada kelompok perlakuan dan kontrol, tetapi penurunan lebih besar terjadi pada kelompok perlakuan. 
Saat mengalami stress atau kecemasan yang berlebih, otak akan menstimulasi HPA-axis di korteks cerebri yang akan mempengaruhi hipotalamus untuk mensekresikan CRF (corticotrophin releasing hormone). Selanjutnya hypothalamus akan memacu hipofisisanterior unuk memproduksi ACTH (adrenocorticotrophic hormone). Kemudian ACTH akan merangsang korteks adrenal untuk melepaskan hormone kortisol (hormone stress). Hormon kortisol dalam jumlah tinggi di aliran darah akan membuat produksi hormon di dalam tubuh tidak seimbang yang akan menekan system imun tubuh dan menimbulkan respon cemas maupun stress. peningkatan kortisol akan menyebabkan terjadinya peningkatan tekanan darah, peningkatan glukosa darah dan peningkatan irama jantung (Guyton, 2008).

Titik acupoint merupakan sel aktif listrik yang disebut gate of energy dan mudah berpolarisasi dan membentuk energi dalam batas menyeimbangkan alur energi (Qi) yang ada sehingga terciptanya harmonis dan proporsional antara unsur Yin dan Yang (Widya, 2012). Pemberian stimulasi pada titik akupresur akan merangsang reseptor syaraf dimana rangsangan tersebut akan dikirim bagian pons dilanjutkan ke bagian kelabu pada otak tengah (periaquedektus), rangsangan yang diterima oleh periaquedektus disampaikan kepada hipotalamus, dari hipotalamus inilah melalui alur syaraf desenden hormon endorphin dikeluarkan ke pembuluh darah serta meningkatkan regulasi kortisol serum. Endorphin adalah opiat alami yang diproduksi dalam tubuh, yang memicu respons menenangkan dan membangkitkan semangat di dalam tubuh, memiliki efek positif pada kestabilan emosi, mengurangi kecemasan, menyebabkan relaksasi dan normalisasi fungsi tubuh (Hmwe NTT et al, 2015; Stratton, 1982).

Akupresur dapat menghasilkan serta menyeimbangkan, energi $Q i$, keseimbangan, terciptanya harmonis dan proporsional antara unsur Yin dan Yang dan sekresi neurotransmitter, sehingga mempertahankan fungsi normal tubuh manusia dan memberikan kenyamanan. Semua efek yang disebutkan akupresur dapat mengurangi kecemasan (Shariati et al, 2012). Pada penelitian ini pemilihan titik- titik akupresur ditujukan pada penderita yang mengalami kecemasan dan gangguan penurunan kualitas tidur pada pasien AMI, sehingga perlu mengkombinasikan beberapa titik. Titik-titik intervensi yang dipilih adalah titik jantung shen men (HT-7), titik selaput jantung neiguan (PC-6) dan titik limpa san yin jiao (SP-6) untuk mengatasi kecemasan, kesulitan masuk kedalam tidur serta gangguan tidur lainnya dan dan titik istimewa titik tay yang (EX-5) dan yintang (EX-3) untuk memberikan perasaan relaksasi (Adikara, 2015; Sukanta, 2008).

Hasil ini sesuai dengan penelitian yang dilakukan sebelumnya oleh Nant Thin Hmwe et al yang melakukan akupresur pada titik yintang (ex-3), shenmen (HT7) dan taixi (KI3) selama 15 menit sebanyak 3 kali seminggu selama 4 minggu secara signifikan mengurangi kecemasan $(p=0,001)$ pada 22 pasien yang menjalani hemodialisis (Hmwe NTT et al, 2015). Hasil yang sama didapatkan pada penelitian Mansoorzadeh et al bahwa akupresur menurunkan kecemasan pada 35 pasien yang menunggu pemasangan angiografi, setelah dilakukan akupresur pada titik ear shenmen (HT7) dan ying-tang (EX- 3) selama 10 menit, terdapat penurunan kecemasan secara signifikan $(\mathrm{p}<0,001)$ dimana akupresur bermanfaat sebelum dilakukan prosedur tindakan kritis (Mansoorzadeh et al, 2014). Hal ini menunjukkan bahwa akupresur efektif dalam menurunkan kecemasan.

Akupresur merupakan terapi dengan prinsip healing touch yang lebih menunjukan perilaku caring pada responden, sehingga dapat memberikan perasaan tenang, nyaman, perasaan yang lebih diperhatikan yang dapat mendekatkan hubungan terapeutik antara 
peneliti dan responden (Yudi, 2014). Dari aspek psikologis akupresur membantu mengurangi kecemasan responden. Sebagian besar responden mengatakan bahwa dengan terapi akupresur mereka merasa lebih diperhatikan, merasa tenang, nyaman dan rileks.

Penekanan pada pendekatan ilmiah dan terapi telah menjadi kunci dalam mengembangkan dan menyempurnakan model terapi yang ada. Pikiran dan tubuh memiliki hubungan yang saling tergantung mudah dibuktikan dalam konteks keagamaan, namun kurangnya pengakuan akan hubungan tersebut dalam pendekatan terapeutik kontemporer berarti bahwa pasien tidak dapat memperoleh manfaat dari penggunaannya dalam sesi. Hubungan antara fungsi jantung dan otak yang dibuktikan dengan rujukan singkat pada ayat-ayat Al-Quran dan penelitian medis yaitu neurokardiologis. Konsep 'heart talk' adalah perpanjangan dari istilah 'otak jantung' yang diciptakan oleh Dr Armor (Profesor Farmakologi) pada tahun 1991 dan sugestif penggunaannya dalam dunia terapi psikologis. Ini berhubungan dengan kognisi pasien yang datang dari hati yang secara sugestif memiliki beberapa dasar ilmiah dan berpotensi menjadi sumber informasi dalam memahami perasaan pasien (Hussain F, 2013). Kombinasi murottal dan akupresur menunjukkan hubungan pada konsep hearttalk antara fisiologis dan psikologis.

Hasil penelitian menujukkan bahwa terdapat perbedaan yang signifikan secara keseluruhan terhadap gula darah setelah diberikan murrotal dan akupresur pengukuran 1 dan pengukuran 2 namun intervensi murotal dan akupresur tidak berpengaruh signifikan secara statistik dalam menurunkan gula darah responden baik pada kelompok Intervensi maupun kelompok kontrol. Tidak ada perbedaan yang bermakna antara gula darah kelompok intervensi dengan kelompok kontrol pada pre, pengukuran 1, pengukuran 2 $(\mathrm{p}=0.748, \mathrm{p}=0.728, \mathrm{p}=0.789)$. Kedua kelompok sama-sama mengalami penurunan gula darah. Walaupun demikian baik kelompok intervensi maupun kelompok kontrol tidak menunjukkan pengaruh yang signifikan di setiap pengukuran.

Akupresur bisa mengaktifkan glucose-6-phosphate (salah satu enzim metabolisme karbohidrat) dan bisa berefek pada hipotalamus. Akupresur bekerja pada pankreas untuk meningkatkan sintesis insulin, meningkatkan salah satu reseptor pada sel target, dan mempercepat penggunaan glukosa didalam sel, sehingga hasilnya adalah menurunkan kadar gula yang ada di darah. Titik-titik akupresur yang sering digunakan adalah pada Pishu (BL 20), Feishu (BL 23), Shenshu (BL 23), Zusanli (ST 36), Sanyinjiao (SP 6), Hegu (LI 4) (Ingle et al, 2011). Sensitifitas insulin akan baik ditambah dengan meningkatnya GLUT 4 sehingga menyebabkan kapasitas untuk membawa glukosa serta pemakaian glukosa dalam sel juga akan semakin meningkat (Masithoh RF et al, 2016).

Pemberian terapi murottal dengan akupresur memberikan efek relaksasi pada pasien jantung koroner. Kondisi relaks dapat menunrunkan kadar gula darah karena dapat menekan pengeluaran hormon-hormon yang dapat meningkatkan kadar gula darah yaitu epinefrin, kortisol, glukagon, adrenocorticotropic hormone (ACTH), kortikosteroid, dan tiroid. Epinefrin beraksi pada hati dengan meningkatkan konversi glikogen menjadi glukosa dalam keadaan stress. Sedangkan kortisol memiliki efek meningkatkan metabolisme glukosa sehingga asam amino, laktat, dan piruvat dapat dibuah menjadi glukosa (glukoneogenesis) akhirnya menaikkan kadar gula darah. Glukagon meningkatkan kadar gula darah dengan cara mengkonversi glikogen menjadi glukosa sehingga gula darah menjadi naik. ACTH dan glukokortikoid pada korteks adrenal dapat meningkatkan kadar gula darah dengan cara meningkatkan pembentukan 
glukosa baru oleh hati. Kondisi relaksasi bekerja menurunkan kadar gula darah dengan cara menghambat proses-proses tersebut (Kuswandi, 2008).

Fluktuasi nilai kadar gula darah sewaktu dipengaruhi oleh banyak faktor, antara lain adalah kemampuan responden dalam beraktifitas, kemampuan responden dalam asupan nutrisi sediaan rumah sakit dan kepatuhan terhadap ketersediaan diit dari rumah sakit. Gangguan kardiovaskuler menyebabkan responden mengalami sesak nafas karena terjadi penurunan cardiacout put. Kondisi demikian kurang memungkinkan bagi responden untuk beraktifitas yang cukup guna memasukkan glukosa darah ke dalam sel, hal ini berakibat kecenderungan terjadinya peningkatan nilai kadar gula darah sewaktu pada pasien dengan gangguan kardiovaskuler (Nugraha, 2015).

\section{SIMPULAN}

Terapi murottal dengan akupresur terhadap kecemasan berpengaruh dalam menurunkan kecemasan pasien jantung koroner pada pengukuran 1 dan pengukuran 2; Terapi murottal dengan akupresur dan terapi murottal tidak pengaruh terhadap gula darah pada pengukuran 1 dan pengukuran 2; Terapi murottal dengan akupresur dan terapi murottal terhadap tingkat kecemasan dan kadar gula darah dapat disimpulkan bahwa terapi kombinasi antara murottal dengan akupresur selama 2x15 menit sehari lebih efektif dalam menurunkan kecemasan dan tidak berpengaruh terhadap kadar gula darah.

\section{SARAN}

Untuk pelayan keperawatan, terapi kombinasi murottal dan akupresur dapat diaplikasikan untuk menurunkan tingkat kecemasan pada pasien dan memberikan kenyamanan pasien.

Untuk institusi pendidikan, penelitian ini dapat menjadi rujukan dan kajian serta pengembangan pengetahuan mengenai terapi holistik dalam upaya menurunkan kecemasan pasien khususnya pasien jantung.

Untuk peneliti selanjutnya dapat mengembangkan penelitian dengan menganalisis factor-faktor resiko yang dapat mempengaruhi kecemasan lebih jauhdan yang dapat mempengaruhi kadar gula darah pada pasien jantung.

\section{DAFTAR PUSTAKA}

Adikara M, S. (2015). Materi Pelatihan Akupresure Dasar. Surabaya: Acasi

Al-Kaheel. (2011). Al-Qur'an the Healing Book. Jakarta: Tarbawi Press

An K., De Jong, M. J., Riegel, B. J., McKinley, S., Garvin, B. J, Doering, L. V. (2004). A Cross-Sectional Examination of Changes in Anxiety Early after Acute Myocardial Infarction. Heart \& Lung: The Journal of Acute and Critical Care, 33(2), 75-82. https://www.ncbi.nlm.nih.gov/pubmed/15024372

Endiyono, Y. P. (2016). Pengaruh Terapi Murottal Al-Qur'an Surat Ar-Rahman terhadap Kualitas Tidur Pasien di Ruang ICCU RSUD Prof. Dr. Margono Soekarjo Purwokerto. Medika Respati, 11(2). http://repository.ump.ac.id/2251/

Faradisi, F. (2012). Efektivitas Terapi Murottal dan Terapi Musik Klasik terhadap Penurunan Tingkat Kecemasan Pasien Pra Operasi di Pekalongan. Jurnal Ilmiah Kesehatan (JIK), 5(2). http://id. portalgaruda. org/?ref= browse\&mod= viewarticle\&article $=119550$

Guyton, A. J. C. (2008). Fisiologi Kedokteran (Textbook of Medical Physiology). Jakarta: EGC 
Hmwe, N. T. T., Subramanian, P., Tan, L. P., Chong, W. K. (2015). The Effects of Acupressure on Depression, Anxiety and Stress in Patients with Hemodialysis: A Randomized Controlled Trial. International Journal of Nursing Studies, 52(2), 509-18. https://www.sciencedirect.com/science/article/pii/S002074891400296X

Ingle, P. V., Samdani, N. R., Patil, P. H., Pardeshi, M. S., \& Surana, S. J. (2011). Application of Acupuncture Therapy in Type 2 Diabetes Mellitus Patients. Pharma Sci Monit, 2(1). Retrieved from www.pharmasm.com

Islamee, A. U. (2008). Faktor-Faktor Risiko Penyakit Kardiovaskular yang Berhubungan dengan Adanya Kelainan Elektrokardiografi pada Jamaah Mejelis Dzikir SBY Nurussalam Tahun 2008. Jakarta: Universitas Indonesia

Kasron. (2012). Kelainan dan Penyakit Jantung. Yogyakarta: Nuha Medika

Kuswandi, A., Sitorus, R., Gayatri, D. (2008). Pengaruh Relaksasi terhadap Penurunan Kadar Gula Darah pada Pasien Diabetes Mellitus Tipe 2 di Sebuah Rumah Sakit di Tasikmalaya. Jurnal Keperawatan Indonesia, 12(2)

Lestari, D. (2015). Pengaruh Terapi Murottal terhadap Tingkat Kecemasan Pasien dengan Penyakit Jantung Koroner di Ruang ICCU RSUD dr. Soedarso Pontianak. ProNers, 3(1). http://jurnal. untan. ac. Id /index. php/ jmkeperawatanFK /article/view/10530

Majid, Y. A., Fatimah, S., Susanti, R. D. (2014). Pengaruh Akupresur terhadap Kualitas Tidur Lansia di Balai Perlindungan Sosial Tresna Werdha Ciparay: Universitas Padjadjaran

Malan, M. S., Hemmings, S. M. J., Seedat, S. (2013). Big Effects of Small RNAs: a Review of Micrornas in Anxiety. Molecular Neurobiology, 47(2), 726-39. https://www.ncbi.nlm.nih.gov/pubmed/23150170

Mansoorzadeh, K., Afazel, M., Taghadosi, M., Gilasi, H., Kashan, I. (2014). The Effect of Acupressure on Anxiety and Dysrhythmia in Patients Undergoing Cardiac Catheterization. Life Science Journal, 11(1), 153-7. http://eprints.kaums.ac.ir/436/

Mardiyono. (2012). The Effects of Nursing Based Intervension Integrating Islamic Relaxation on Anxiety and Perceived Control in Indonesian Patients with Acute Myocardial Infarction Admitted in ICCU. Thailand Prince of Songkla University

Masithoh, R. F., Ropi, H., Kurniawan, T. (2016). Pengaruh Terapi Akupresur terhadap Kadar Gula Darah pada Pasien Diabetes Melitus Tipe II di Poliklinik Penyakit dalam RS Tk II Dr. Soedjono Magelang. Journal of Holistic Nursing Science, 3(2), 26-37. http://journal.ummgl.ac.id/index.php/nursing/article/view/872

Nielson, C., Lange, T., Hadjokas, N. (2006). Blood Glucose and Coronary Artery Disease in Nondiabetic Patients. Diabetes Care, 29(5), 998-1001. https://www.ncbi.nlm.nih.gov/pubmed/16644627

Nugraha, D. A. (2017). Efek Hipnopresur terhadap Kecemasan pada Pasien dengan Gangguan Kardiovaskuler. Semarang: Poltekkes Kemenkes Semarang

Rufaidah, M. F. (2015). Penilaian Tingkat Risiko dan Faktor-Faktor yang Berhubungan dengan Penyakit Jantung Koroner pada Masyakarat Binaan KPKM Buaran FKIK UIN Syarif Hidayatullah Tahun 2015

Setiawan A. (2016). Hubungan Tingkat Kecemasan dengan Kadar Gula Darah Puasa pada Pedagang Pasar Klewer Pasca Kebakaran: Universitas Sebelas Maret

Soeharto I. (2004). Penyakit Jantung Koroner dan Serangan Jantung. Penerbit PT Gramedia Pustaka Utama, Jakarta

Sukanta, P. O. (2008). Pijat Akupresur untuk Kesehatan. Jakarta: Penebar Plus 
Sundström, J., Evans, J. C., Benjamin, E. J, Levy, D., Larson, M. G., Sawyer, D. B. (2004). Relations of Plasma Total TIMP-1 Levels to Cardiovascular Risk Factors and Echocardiographic Measures: The Framingham Heart Study. European Heart Journal, 25(17), 1509-16. https://www.ncbi.nlm.nih.gov/pubmed/15342170

Widyatuti, W. (2008). Terapi Komplementer dalam Keperawatan. Jurnal Keperawatan Indonesia, 12(1), 53-57. http://jki.ui.ac.id/index.php/jki/article/view/200

Wiyatno ER. (2017). Pengaruh Akupresur terhadap Kecemasan, Kualitas Tidur dan Status Hemodinamik Pasien Acute Myocardial Infarction. Semarang: Poltekkes Kemenkes Semarang

Yudi, A. M. (2014). Pengaruh Akupresur terhadap Kualitas Tidur Lansia di Balai Perlindungan Sosial Tresna Werdha Ciparay: Universitas Padjadjaran Bandung 